\title{
Strengthening Local Identity by Writing Chronicles in the EFL Classroom
}

\section{Fortalecimiento de la identidad local a través de la escritura de crónicas en el aula de inglés}

\section{Alba Milena Flórez González¹}

Citation/ Para citar este Artículo: Florez, A. (2018). Strengthening Local Identity by Writing Chronicles in the EFL Classroom. Colomb. Appl. Linguistic. J., 20(2), pp. 195-208.

Received: 05-Feb.-2018 / Accepted: 21-Jun.-2018

DOI: https://doi.org/10.14483/22487085.13121

\begin{abstract}
This action research study sought to incorporate students' local identity as the set of traditions, language, history and norms of conduct as a potential element to enhance the foreign language learning process. The purpose of this study was to strengthen local cultural identity in high school students, facilitating a meaningful foreign language learning process and promoting the active participation of students in their local communities (Sharkey, Clavijo, \& Ramirez, 2016), through inter-generational dialogue. The research questions proposed were: a) what were the perceptions students had about their local identity? and b) how did high school students strengthen their identity by writing chronicles in English class about their family history? Findings posit the impact of the study on students' perception about their local identity, how they proudly identify themselves as Villanuevas (people from Villanueva), their active involvement in the community by fostering an intergenerational communication, the improvement on the students' L2 competence as well as the impact of the sutdy on the researcher teaching process and its cross curricular influence.
\end{abstract}

Keywords: chronicles, EFL classroom, foreign language learning, local identity, writing process

\section{Resumen}

Esta investigación acción define la identidad local como el conjunto de tradiciones, lenguaje, historia y normas de conducta de los estudiantes como un elemento potencial para mejorar el proceso de aprendizaje de una lengua extranjera. El propósito de la investigación fue fortalecer la identidad local en los estudiantes desde la clase de inglés, facilitando un proceso de aprendizaje significativo y promoviendo la participación activa de los estudiantes en su comunidad (Sharkey, Clavijo, \& Ramirez, 2016), a través del diálogo intergeneracional. Las preguntas de investigación propuestas se centraron en conocer a) cuáles eran las percepciones que los estudiantes tenían sobre su identidad local, y b) de qué manera los estudiantes fortalecían su identidad mientras escribían crónicas acerca de la historia de su familia, en clase de inglés. Los resultados muestran la forma como los estudiantes interactuaron con su comunidad, conocieron más acerca de su historia y fortalecieron su identidad local y sus competencias en la lengua extranjera, mejoras reflejadas principalmente en el proceso de escritura de los estudiantes.

Palabras clave: crónicas, clase de inglés, aprendizaje de una lengua extranjera, identidad local, proceso de escritura

$\overline{1}$ Colegio Eliseo Pinilla Rueda, Villanueva, Colombia. jaftami@gmail.com 


\section{Introduction}

Local identity is the construction that all individuals make of their reality according to the society in which they live (Lin, 2009). This construction is normally permeated by the economic, educational, and social realities of the context in which people are immersed, and it helps them create a relationship characterized by a set of shared beliefs, traditions, and cultural practices. Similarly, Norton (2006) argues that local cultural identity is the relationship an individual has with the members of a specific social group with a common history, language, and understanding of the world. In the same way, Jandt (2012) describes local identity as the identification and acceptance into a group with a shared system of symbols and established norms for conduct. From these three definitions, I assert that local identity is the way that we identify ourselves as members of a community and as the manner in which the traditions, beliefs, and practices we share with that community can affect the way we see and conceive the world around us.

Language is closely related to the construction of identity. This is supported by Lin (2009) who argues that learning a language is not just the learning of a code, but is also an intercultural enterprise in which learners explore the cultural practices of foreign social groups. In other words, learning a language is a social practice in which new experiences come into the learner's life and create a space for the negotiation of identities (Norton, 2011). In a slightly different understanding of the relationship between language and identity, Ariza (2007) explains that "language can be seen as a way of describing and presenting human experiences of the world" (p. 11), those experiences that construct and enrich the local identity. This is to say that languages provide a means to spread and access different worldviews.

Even though we are involved in a particular community with a set of features that define our local identity, globalization has facilitated a clash of cultures which is transforming the way we understand our own reality and identity. A clear example of this cultural clash is the way youth seem to be adopting social practices learned through mass media and not necessarily related and relevant to their particular contexts. Here, Norton's (2011) notion of imagined communities is particularly helpful since she defines imagined communities as those social groups to which individuals aspire to belong. In our case, today's youth wish to become part of communities that are not relevant to the local contexts where they live and whose cultural practices are alien to their lives.

In this scenario, the school presents itself as a site of resistance where efforts to strengthen local identities can be made. Álvarez and Medina (2009) explain how the study of one's culture in the foreign language class is a process through which students can understand their own realities in light of the realities and points of view of others. This suggests that the use of a foreign language can help students to reflect on their own practices in order to make comparisons with the target culture. At this point, globalization, more than a disadvantage, can be seen as an opportunity to interact with others and to get to know different representations of the world, allowing us to appreciate and understand the uniqueness and peculiarities of our own culture. In this regard, Wang (2007) proposes seeing local identity as a tool which provides people with a global view of local knowledge and helps construct a positive sense of self, community, and nation.

In particular, the central goal of this action research project was to provide students with opportunities to explore the traditions, beliefs, and history that constitute their identity as Villanuevas. With this in mind, this study attempted to answer two research questions: a) what are the perceptions students have about their cultural identity? b) how do high school students strengthen their cultural identity by writing chronicles in English class about their family history?

\section{Literature Review}

There are solid reasons to attempt to strengthen students' local identity in a foreign language educational setting. To being, it may improve students' local knowledge and foster participants' active relationship with the community through spaces of communication where elders share their 
experiences with them. Second, students' language skills can be meaningfully enhanced since even when they are learning a foreign language, data used in the process are part of their everyday context. Third, the use of local knowledge in foreign language learning allows participants to know and better understand their own culture and be open to knowing the L2 culture without acculturating. That is, the use of local knowledge in English class as expressed by Cakir (2006) connects one's own culture with others in more dynamic scenarios.

Thus, strengthening students' local identity from the EFL classroom as an integrative process involves using the students' own first and foreign language to express feelings, beliefs and emotions, motivation, and the teacher's guide and support. Consequently, this literature review focuses on four main themes related to the construction of cultural identity: a) globalization and local practices, b) relationship between language and culture, c) building cultural identity through English as a foreign language class, and d) writing as a tool in the construction of cultural identity.

\section{Globalization and Local Practices}

Globalization is a worldwide phenomenon and it is impossible to deny its existence and its continuous controversial expansion around the world. Its principles and impact on communities have been largely the object of discussion in the last decades; however, as a unified vision of globalization has not yet been reached, there are different perspectives to seeing and understanding this phenomenon. On the one hand, there are people who present arguments against globalization claiming that it is a strategy from developed countries to establish a global socioeconomic society without considering local diversity. As Popa (2012) suggests, globalization has destabilized democracies and cultures in favor of the global elites. On the contrary, some people support the idea of globalization as an opportunity to show local practices in global scenarios. To this regard, Rafat, Emadzadeh, and Ahmadi (2013) argue that local communities which expand their vision and give open access to international settings take the best of local and global knowledge and increase their understanding of themselves and the understanding of the dynamics of the world while improving their living standards.

Both the negative view and the one highlighting the contributions of globalization to the strengthening of local identities make strong points. For this study, however, the positive conception of the impact of globalization was adopted since this process could be understood as a social phenomenon which more than destroying identities, fosters and helps them to be known and shared around the world. As Örnek (2003) found, globalization can make individuals more aware of their local identity and create within them the need to protect and preserve the features that make them particular and unique. Wang (2007) agrees with Örnek saying that living in the era of globalization, people pay more attention to the particularities their local identity offers as a way to distinguish it from others. In this regard, globalization is conceived of as a practice of social exchange where local identity more than disappearing, emerges from its uniqueness and compares to other identities to enrich an intercultural approach.

\section{Language and Culture}

Language is a strong determinant in the construction of local cultural identity as there is no culture separated from language or a language that does not consider any local culture in its development. To this regard, Norton (2006) proposes the construction of identity through language since the latter is present in all the context of all learners and provides them with the voice to express their value systems which are part of the local culture they feel identified with. In a similar way, Ariza (2007) sees language as a tool that human beings use to describe their experiences and the way the world is represented. Thus, language is a way to communicate culture, to share the social features composing identity in order to develop intercultural competence where learners understand that there are several cultures but all of them are valuable and unique.

The arguments presented above work on the assumption that language is not only related to, but is an important part in the construction of local identity. In this regard, Lin (2009) also argues that 
a language cannot only be understood as a code but as a set of social elements which surround it and nourish it, thus affecting language learning either positively or negatively. In short, local identity is constructed and strengthened through language because it is the medium through which it spreads.

\section{Bringing Local Identity through English as a Foreign Language}

According to Ariza (2007), local identity is defined as the construct of behaviors, beliefs, and social thoughts that people identify with and which make them part of a community. In a similar fashion, Frank (2013), points out that local culture is not only related to food or clothes, but it also considers the ideology and traditions that build a common society. This means that local identity is not a static linear process, but a social construction that is developed through interaction with others. Wang (2007) continues to argue that local identity is a plan created by people to develop future activities based on past experiences. It means that this identity is not only developed with the current experiences individuals face but also by those previous interactions which could affect the way they see and understand the world as well as their value systems.

Considering that cultural identity is developed in interaction, school plays an important role in its construction and development. Thus, by using authentic materials in the classroom, it is possible to help students in the understanding of their own values and beliefs (Ariza, 2007). But when this strengthening of identity is observed from the foreign language perspective, it is necessary to pay attention to the influence of the L2 culture in the process of construction and maintenance of the L1 cultural identity. In light of this understanding, it is necessary that students take a critical position, knowing and analyzing the target culture but always recognizing the mother culture they are part of (Álvarez \& Medina, 2009).

\section{Writing as a Tool in the Construction of Identity}

In this study, the strengthening of local identity was addressed within the EFL classroom and, in particular, through the process of writing. It was seen as a strategy to improve competence in the foreign language and at the same time the learners' engagement with knowing their local identity and the opportunity to share it with others. Writing has been shown as the most difficult skill to be developed by learners since it is a conscious process that considers grammar features and the sociocultural aspects affecting it (Lombana, 2009). This first definition of writing shows how it is understood beyond the simple use of grammar rules to produce texts, but it also considers the ideologies and beliefs the writer has when he or she is creating their writing piece. Another view of writing is given by Ahmed (2011) who sees writing as a process in which learners are in a constant struggle to find ways to weave their ideas using the correct words to express themselves through writing. This is one of the reasons why writing is so difficult; frequently, the ideas people put on paper do not say what they mean. In a slightly different understanding of writing, Chala and Chapetón (2009) present writing as a process in which students can become involved in social events and share those events with people who are not part of the same community. This is a wider view of writing that points out the power it has to connect people around the world even when they do not bear a part in the same value system.

Similarly, Fulton et al. (2005) highlight the importance of introducing the learner to different cultures while always providing spaces for the analysis and awareness of their own local culture. That is to say, more than fostering the strengthening of a closed local identity, it is essential to work on an intercultural sense of belonging that makes students familiar with foreign cultures while they are learning a foreign language, but keeping their own roots and beliefs.

In short, there are as many identities as languages in the world and each one of them is unique. The purpose is not to abandon the local identity in favor of that of the target language, but understanding and being identified with one's own system of traditions in order to establish connection with others. Imposing one's own group of values on others while neglecting variety is not the best way to communicate or establish relationships 
(Suneetha, \& Sundaravalli 2011). Keeping traditions but being open to share them with others is a good way to strengthen local identity and to be more interculturally competent.

\section{Methodology}

Considering that the research questions aimed at understanding students' perceptions of their local identity and how they could strengthen such an identity by writing chronicles in English class about their family history, this study was framed within the principles of action research. That is, it was oriented towards working with a social issue observed by the teacher in the daily teaching process and which could be approached via an intervention in the classroom following the process of planning, acting in context, observing, and reflecting on the action.

To this regard, Corey (1953, cited in Cohen et al., 2007) explains that "action research is a process in which practitioners study specific situations in order to evaluate, improve and steer decision making and practice" (p. 297). Considering this definition, action research is a process that involves the teacher's participation and support and the students' active involvement and commitment since it is a profound practice of reflection and use of strategies guided to improve action. In a slightly different way, Cohen et al. (2007) describe some main characteristics of action research which are closely related to the study described here, for instance its collaborative nature which enhances the competences of participants, and the use of strategies to promote problem solving and critical thinking improving the classroom practices and community social development.

\section{Participants}

The sample population for this research project was chosen by following the convenience sampling principles stated by Cohen et al (2007). They express that in this kind of sample, researchers choose the participants taking into account people who they have easy access to. That is, those who are available and accessible at the time, for this specific case, one group of students of eleventh grade was chosen. The sample was formed by 33 students, 23 women and 10 men from 15 to 18 years old, and who had been classified in an A1-A2 English Level according to the Common European Framework of Reference for Languages and based on a placement test administered at the beginning of the school year.

\section{Data Collection Instruments}

Data came first from a questionnaire given to students before the intervention with the intention of understanding the perceptions they had about their cultural identity. Before writing the items of the questionnaire, a matrix was designed considering the concept of cultural identity. This concept was broken down into categories such as relationship with the social group, socioeconomic status, educational level, sharing of a common history, students' language and understanding of the world. The questionnaire was completed with a sociodemographic chart and was written in Spanish in order to ensure the students complete understanding.

While the writing process was being carried out, I took class field notes in a research journal to monitor the progress of students, the achievement of the activities proposed in the lesson plans, and to make decisions in the teaching learning process. This journal became an important instrument to gather data and served to the purpose to know how high school students were strengthening their local identity from throughout the writing of the chronicles. Dörnyei (2007) states that journals are systematic written documents as diaries followed especially by researchers in order to reflect on, analyze their investigation, and make decisions for the future of the projects.

Finally, a focus group was designed to be administered at the end of the pedagogical intervention to examine the impact that the research had on the participants and to search for information regarding the second research question: how do high school students strengthen their cultural identity by writing chronicles about their family history in the English class? This data collection instrument was designed to complement the data gathered from the research journal because as it is expressed by Cohen et al. (2007) it provides students with the 
comfort of a small group of people to share and the confidence to generate a rich discussion without being inhibited.

\section{Intervention}

The pedagogical intervention understood as the action plan and practice of the study was designed taking into account the objectives and the two research questions posted. This intervention was guided by the principles of the community based approach (CBA) which promotes interaction between students and the local context. CBA also allows teachers to create a link between the subject-in this case English-and the local culture students are involved in by including activities in which students interact inside and outside the classroom taking advantage of their own local cultural richness, as a useful tool in the language curriculum. The significance, then, comes from the fact that "Community Based Approach is about students having a voice in their own education" (Berg, Blank, \& Mellaville, 2006, p.27) That is to say, information is taken from the students' context and after a process of inquiry, facts, and experiences become useful in the understanding of reality within the communities.

Although some people may regard the community based approach as prioritizing community knowledge to the expense of language, this is not necessarily the case (Morgan, 1998, cited by Pennycook, 2004). This new view of learning organizes language around the experiences lived by the students to create a meaningful sense of language and a more profound understanding of the community surrounding the learners. A specific example was the way the students felt motivated to participate in class when they were discussing their family history, traditions, or values, which occurred because they felt confident talking about what they knew, even if they were doing it in English and their level in the language was not advanced.

Moreover, the community based approach is a great opportunity for teachers to leave the comfort zone of scripted curriculum which limits them and their students and does not foster autonomous learning to propose innovative teaching and learning experiences. Teachers have to develop curricular practices and pedagogies relevant to the local knowledge since the imposed curriculum can devalue the cultural, linguistic and sociopolitical knowledge (Sharkey \& Clavijo, 2012).

The intervention was developed through the following stages: a) negotiation of the topics for writing the chronicles. For this first step, students had a free talk and they shared with their classmates the stories told by their grandparents or relatives in family meetings and which were related to the foundation and first years of Villanueva as an independent municipality, then, students organized themselves in groups of three and each group chose the topic they were more interested in. It was necessary to use dialogue to negotiate topics because a couple of groups wanted to investigate about the same. b) Designing of data collection instruments. After choosing the topic, students designed interviews to gather the information necessary for writing the chronicles. This instrument was designed for being applied to elderly people in the community who do not speak English so it was developed in Spanish, but it had all the expert validity process with the help of the Spanish teacher and a piloting before its application. c) Gathering data from seniors in the town. During this step, students visited seniors and asked for their permissions to record or videotape the interviews, take some pictures, and use the information collected to write a chronicle about the history of the town. During this data gathering, an intergenerational communication was developed where elders shared their lived experiences with young students and they became the spokespeople to make the municipality history and traditions public for those who want to know them but do not know Spanish. d) information sharing. In a wholeclass activity, students shared with their classmates the experience they lived during the interview application and all of the relevant information they could extract in order to write their chronicles. While a group was sharing, the rest of the class was able to give feedback, support, and broaden the data by using the information collected in their own interviews. e) information validity. In this stage, students compared the information they collected with other existing resources such as 
history books and YouTube videos, and then they did a triangulation exercise to validate the data gathered. f) organization of information. Students were suggested to use a portfolio where they placed the instrument they had designed and applied as well as the data they had compiled in order to have access to them when necessary during the writing process. Portfolios let the researchers have both evidence and feedback of what they have achieved (Eridafithri, 2015). g) knowing the genre. To begin, the students checked their Spanish notebooks where they had recently studied about the genre and they extracted the main characteristics of it as well as the writing style and the tenses commonly used during the composition. Subsequently, the teacher presented some samples of chronicles in English in which students could identify the parts, tenses, and characteristics they had studied before. The samples were added to the portfolio so that they were available as guides in the coming writing process. g) drafting. An overall idea of the work in this stage could be summarized as the writing of the chronicle by using graphic organizers as the sandwich chart in which students re organized the data they already had following the schema of topic, detail, and concluding sentence. h) facing language demands. While they were writing, the studets faced issues that they did not know or did not remember regarding how to use some grammar tenses or rules; thus, a set of mini lessons were developed at the beginning of each class to facilitate the students' writing process. i) peer reviewing and editing. This stage consisted of a speed meeting strategy applied when students finished a first draft of the chronicle. In this way, they shared with the other groups their experiences during the writing process and presented the chronicle. Each group listened to their classmates, read the composition, and finally gave their own opinions and suggestions. Considering their classmates feedback, students started the editing process and made decisions to improve their papers; and the last stage j) publishing. This happened once students finished the editing process, when after reading and rereading they felt that they had included all the relevant information. The final products of each group were compiled into a book with the name of: Villanueva, Cultural Insights. Figure 1 shows these stages graphically.

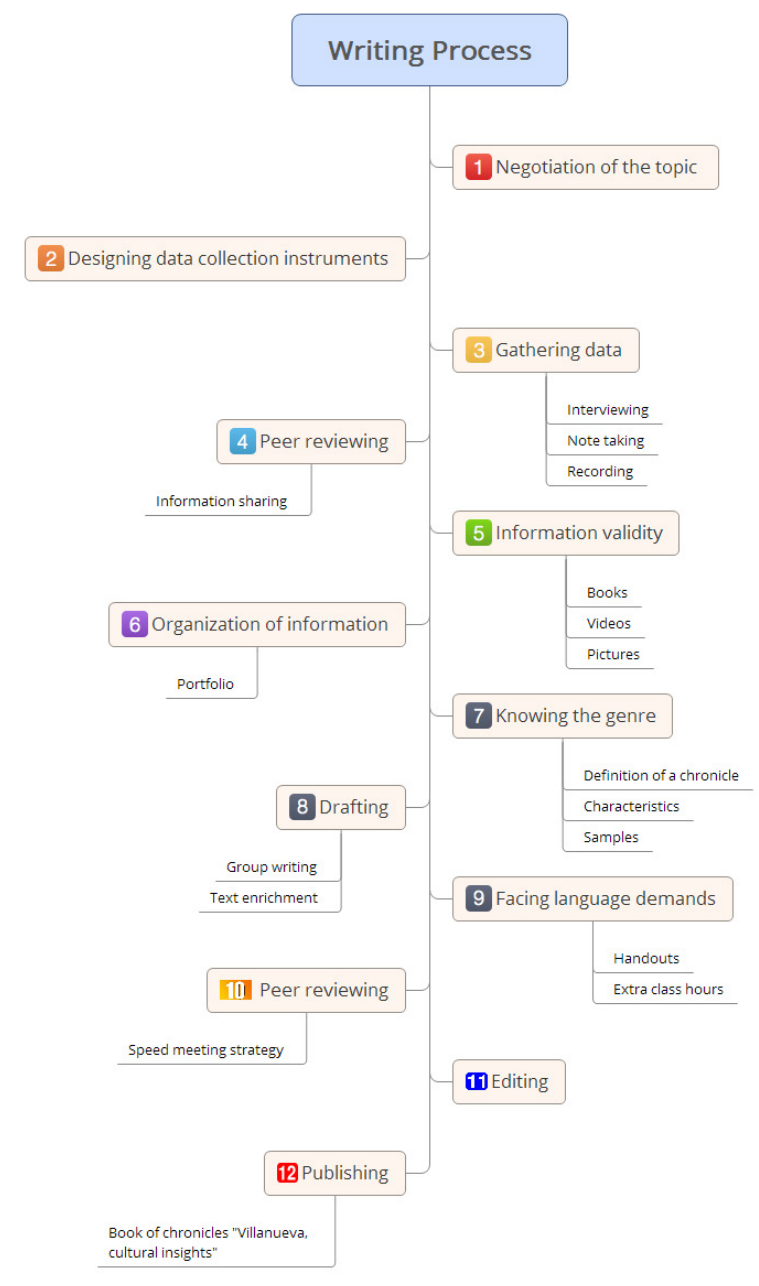

Figure 1. The writing process.

\section{Data Analysis}

Before describing the techniques used in data analysis, it is important to clarify that in order to ensure the confidentiality of the students' identity and to facilitate the coding and citing of their opinions, the sample was categorized taking into account gender, age, and the geographical location (rural or urban) of each participant. For example, if an individual was the youngest woman of the sample and lived in a rural area, the code she had was F1R.

After considering the ethical issues described above, the techniques used for data analysis were mainly tabulation and interpretation of data, open, 
axial, and selective coding. Tabulation of data permits the researcher an overview of the sample intentions and fits the purpose of data reduction. It also allows the reader to observe similarities and differences between respondents in a more practical and objective way (Cohen et al., 2007). Even though tabulating data is often related to quantitative analysis, it could be employed qualitatively if in addition to organizing the respondents answers, the researcher makes inferences and interpretations of the data - this is what Dörnyei (2007) states as qualitizing data.

The tabulation of information in the data analysis occurred when I used the answers given by the students in the questionnaire as well as the categories from the matrix developed after reading the definition of cultural identity given by authors like Norton (2006), Chang (2010), and Mitchell (2009), in order to understand their perceptions regarding their own local identity. The information let me note the aspects in which students felt more or less engaged with their community and the way they saw and understood the town dynamics.

On the other hand, the coding analysis was developed first with open coding, which occurred when I read and re-read the information collected in the research journal and the focus group transcriptions in order to identify common aspects or codes such as motivation, responsibility, commitment, anxiety, and eagerness. Next, I related them to a specific category, in this case, the students' attitudes and feelings towards their local identity. While the codes were emerging, they were highlighted with different colors to facilitate their later association with broader categories. With this process, the first categories directed to answer the research questions were constructed. After completing the open coding, the next step was to analyze at a more profound level how these categories could be interrelated. Thus, it was necessary to recognize the connections between categories emerging from the analysis of two different instruments and establish the possible similarities or differences. This process is understood as axial coding (Cohen et al., 2007; Dörnyei, 2007). Finally, after analyzing the similarities and differences between categories, I determined the core categories including all the data and previous categories and which were specified and supported by the theory to answer the research questions; that was a selective coding process.

\section{Findings}

From the analysis, four different categories emerged related to the impact of the study at the level of the students, community, researcher, language, and cross curricular level.

\section{Impact at the Students' Level}

This category relates to the ways in which participants may change their vision of people in the town and even the way they now conceive themselves as members of the community. To begin, the students agreed that after the project, they felt that they knew more about the history of the town and they valued more the things they currently had because they were not easy to obtain.

"Mi visión cambió mucho porque aprendí que hay que valorar más las cosas del pueblo y las personas que han dado mucho para tener el pueblo como está" (F20R).

Talking to the elders also allowed them to have an idea of the causes and consequences of violence and price the importance of peace. As one student expressed:

"Como Villanueva aún guardo características como la perseverancia, las ganas de salir adelante y he cambiado las violentas historias de mis antepasados." (F4U)

Similarly, the students stated that when they started to know more about aspects of the local identity such as history, politics, and values of the community, the interest to continue learning increased.

"Como dice el dicho, no hay peor ciego que el que no quiere ver, siempre tuvimos esas historias y nunca nos habiamos interesado en ellas, ahora yo quiero saber más." (F12U) 
As well as self-learning, the wish to share this knowledge with others inside and outside the community also emerged:

"Es importante escribir acerca de la historia de Villanueva para darla a conocer y que haya registros de la fundación y los hechos importantes que han pasado en el municipio." (F1M)

Finally, an interesting conclusion given by one of the female students was how the study empowered and helped her to understand that women are valuable and able to do whatever they want. She concluded this after writing about the role of women in the foundation and first years of the municipality.

"Ahora con más razón veo que las mujeres somos capaces y tenemos iguales derechos para salir adelante." (F10U)

\section{Impact at the Community Level}

Living in a community does not guarantee membership within that community; it is through interaction, communication, and active participation that people understand the way a group of people work, live and are related, and this is the first step to creating a sense of belonging and possible membership. In other words, belonging to a community requires people's desire to know about its traditions, culture, history, and values and the use of this knowledge to help in the decision making and progress of the group. This is known as awareness of local identity. To this regard, Gripaldo (2011) states that a consciousness of local identity implies being proud and feeling identified with aspects of a specific culture, that is, the positive and lasting linkage to a group.

Data analysis revealed how even though most of the students felt identified as Villanuevas, they did not always participate in the activities organized to promote the integration and communication between the inhabitants in the town and for that reason they had just a superficial understanding of important facts as history. That is, the actual involvement in the community, or as Norton (2006) suggested, the belonging to the social group, had not been considered by them as a significant factor in their membership as Villanuevas. On the other hand, after the intervention, the findings revealed that this study impacted the classroom but also the community in two different ways: the way the value systems are conceived and the importance of the intergenerational communication.

Regarding the first level, that is, the value systems, it is important to highlight that Ariza (2007) referred to local identity and its relation to those beliefs and values that a person identifies with and which are common characteristics of the community they belong to. Throughout the research process, students had direct contact with people's beliefs and value systems since they piloted data collection instruments, applied interviews, analyzed data, and asked for pictures. Even in the classroom when they were writing the chronicle, they were discovering those values that people in Villanueva had and which were part of the town's local identity. Once the data were analyzed after the intervention, it was possible to identify the students new vision of their culture. They talked confidently about those values existing in Villanuevas and how they as part of the community also felt identified with and wanted to promote them.

In a slightly different way, the second levelintergenerational communication-was one of the main improvements observed during the study and equated to the opportunity to foster and strengthen the communication between families around a common topic: the history of the town, the independence process, the struggle and difficult times in the very first years of the municipality, and the collaborative work that motivated the progress of the town. This intergenerational dialogue created a sense of union among the people in the town because young learners felt as though they could be part of the history by telling others what their parents and grandparents had to face to establish the municipality. At the same time, the elders in the community felt that they were heard, and their life events had the importance they deserved.

\section{Impact of the Study on the Researcher}

Undoubtedly, after completing this study, the impact could not only be described in terms of the participants; the influence it had on me needs to be considered, too. That is, during the process, the way 
I conceived of and carried out the teaching process was challenged and subjected to changes because of the continuous reflection on the action, planning the activities, directing and monitoring them, facing the students' language demands and making decisions. The pedagogical paradigms taken for granted and perhaps legitimized by me were confronted with new perspectives which required me to reflect again, analyze, and necessarily apply new strategies to improve the teaching and language process.

Table 1 shows the way I was also influenced with the study, that is, that my identity was impacted through the modification of practices in the English class before and after the pedagogical intervention since they moved towards more active actions which foster students' processes of autonomy and metacognition by using their context and their community as a source of information for knowledge.

\section{Impact on the Students' L2 Competence}

Even though the research questions sought to understand students' perceptions of their local identity and how they could strengthen such an identity by writing chronicles in English class about their family history, the classwork activities made it possible to establish the impact the research process had on the students' language skills, especially in writing. After the analysis of the teacher's field notes and the students' responses in the focus group, the main support the study gave to language was, on the one hand, by recycling some grammar topics studied previously and which had not been completely internalized by students. On the other hand, students practiced new grammar tenses which were studied during the process since they were needed to write the chronicle. In addition, throughout the process, students had the opportunity to design and apply data collection instruments which helped them practice brainstorming to generate ideas, in addition to asking questions taking into account the interviewee and the style of the instrument, note taking to obtain relevant information from oral sources in real time, and transcription of information to extract meaningful data to answer the questions posted. Equally important was the students' writing process of the chronicle itself since they had to organize the already collected information in graphics which allowed them to have a more specific idea of how to use it in order to maintain coherence and cohesion. Once the general information was organized, students began writing paragraphs and had to discard information, translate and combine sentences, among other exercises. Also, through the writing process, students practiced peer reviewing activities and note taking from their classmates and teacher's comments to improve their chronicle composition. Finally, they used the field notes to edit the papers taking into account the writing style of the genre. Figure 2 shows the language and writing improvements of the students, identified during the data analysis.

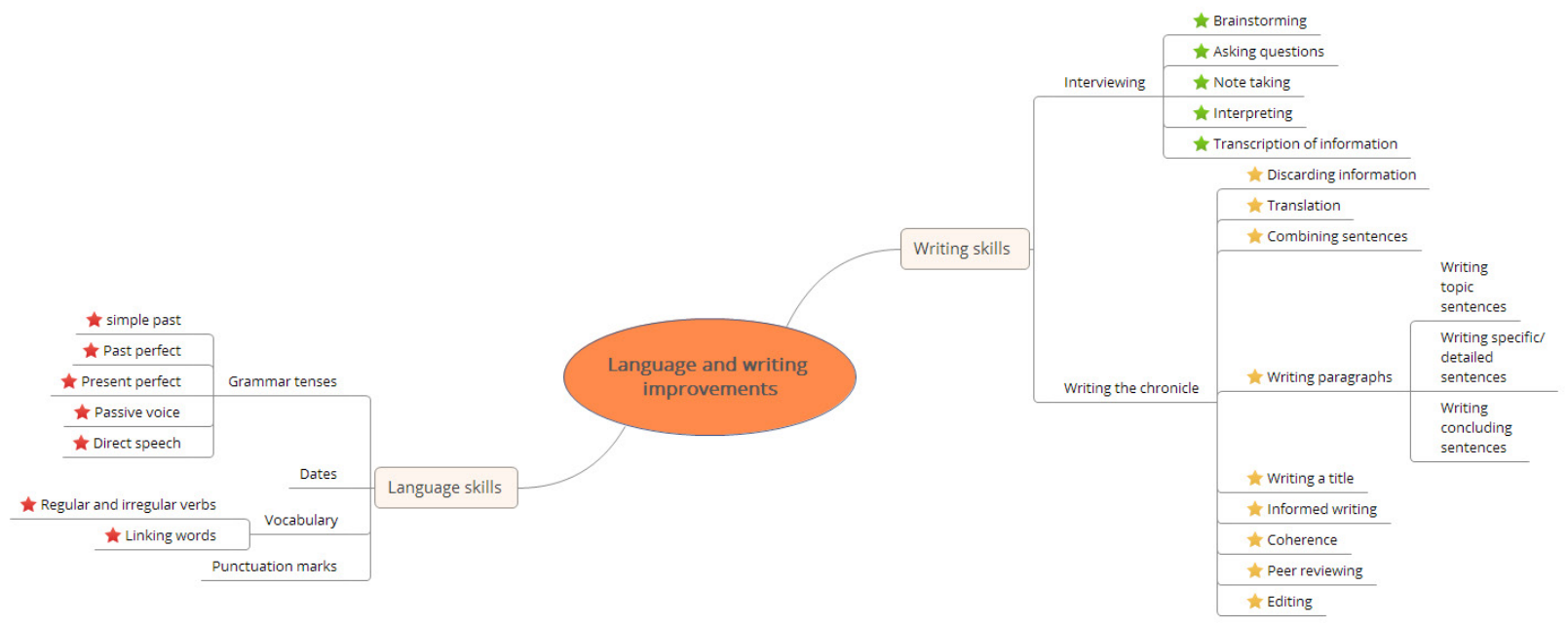

Figure 2. Language and writing improvements. 
Table 1: Reflective Teaching Process.

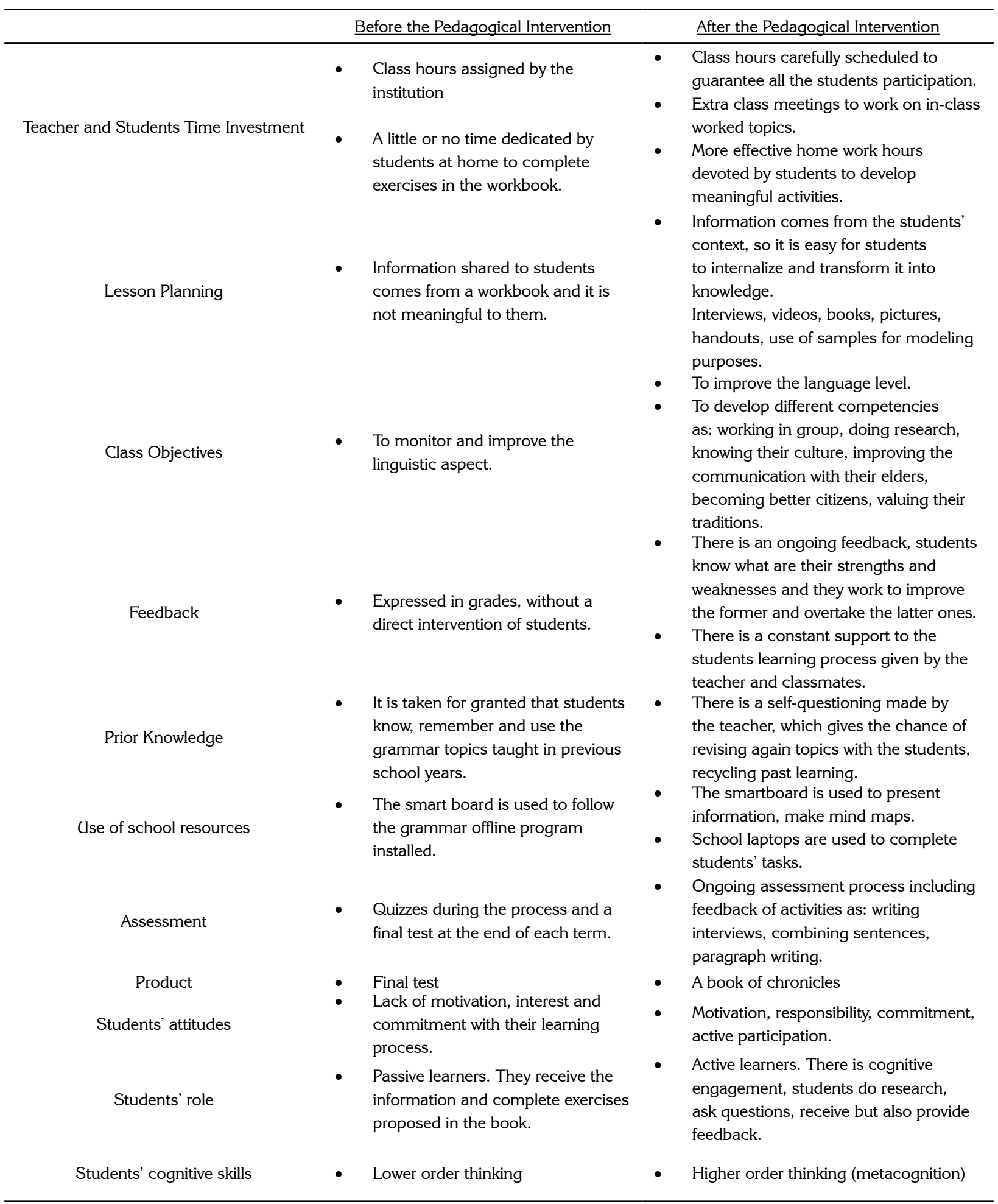




\section{Cross Curricular Impact}

Meaningful classroom activities are those which, even though linked to a definite subject and developed with specific purposes, became tools students can use in other disciplines and even beyond the boundaries of the classroom. An example of these include the learning strategies used during the development of this study in the English class and the way these could enrich the process of other subjects such as Spanish, social studies, and citizenship. First of all, throughout the communication with grandparents and members of the community, students knew more about their history and traditions and they could analyze the present time of the town considering the facts lived in the last decades and related to the foundation of the municipality. This knowledge allowed them to understand social, political, and economic issues which were later debated in social studies classes for further comprehension.

In a similar manner, citizenship sessions were positively impacted with this study since communication between students and their families were fostered as well as the students' interest in history and values of their community. Additionally, throughout the research process, students were able to develop some of the standards proposed by the Ministry of Education in the guidelines 6, Estándares Básicos de Competencias Ciudadanas (MEN, 2004) for instance:

Reconozco que pertenezco a diversos grupos como familia, colegio, barrio, región, país, etc., y entiendo que eso hace parte de mi identidad. Analizo críticamente y debato con argumentos y evidencias sobre hechos ocurridos a nivel local, nacional y mundial, y comprendo las consecuencias que estos pueden tener sobre mi propia vida. Identifico y supero emociones como el resentimiento y el odio, para poder perdonar y reconciliarme con quienes he tenido conflictos. (p. 21)

With regard to the Spanish class and the way it could have been influenced by the study, it is possible to highlight the design and application of the interview made by students to gather data from the elder citizens of the town. During this stage, students practiced how to ask written questions considering the interviewee, how to pilot an instrument, and how to negotiate meaning to obtain relevant information. They also had the opportunity of extracting information and discarding data that were not pertinent for their purposes. Finally, the graphic organizers students used when writing the chronicle fit perfectly when writing essays, stories, short articles in Spanish class and in any other subject. Figure 3 demonstrates the interdisciplinary benefits of the project.

\section{Conclusions}

In response to the first question regarding students' perceptions of their local identity, we see that at the beginning of the research project there were ups and downs. On the one hand, students were optimistic in aspects such as language, common

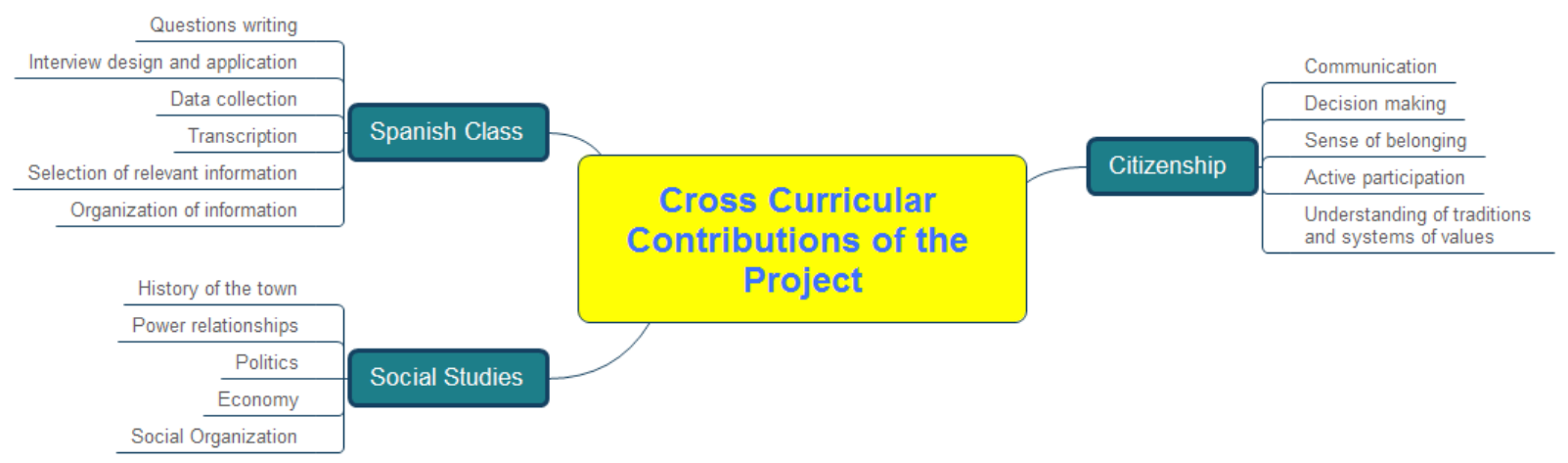

Figure 3. Inter disciplinary contributions. 
history, and the fact that educational level did not affect people's participation in the group. Such a favorable vision of local identity was demonstrated when analyzing the students answers to the items proposed in the questionnaire. On the other hand, there were aspects such as the low participation in activities and the role played by socioeconomic status in the decision making which made students not feel attached or complete members of the community.

The second research question inquired as to how high school students strengthen their local identity by writing chronicles in English class about their family history. In this regard, students felt more interested and motivated to know about their history thanks to the interviews and the stories told by the senior people. They understood the difficult times their relatives faced when the town was founded and the commitment they as the current generation have to maintain the history for their children and also for people who do not know about Villanueva. In other words, students recognized their membership into the group and their role as citizens in the ongoing history making process.

Finally, students' identity was impacted with the research study, but so too was their learning process since learners were constantly using the English language to write the chronicles about their family history. The improvements were described in two directions, first the related with the language itself and second the reinforcement of the writing skill. In the former, students recycled learning and they applied grammar tenses studied in previous school years while they were learning new topics and vocabulary related to the style of the genre. With their writing skills specifically, students improved the way they organized information, did translations, took notes, wrote paragraphs, and edited texts. All of these writing process strategies might be used by students in future English compositions but also in written texts proposed in different subjects and even outside school.

\section{References}

Ahmed, S. A. (2011). Exploring students' perceptions of ESL writing. English Language Teaching, 4(2), 7383. https://doi.org/10.5539/elt.v4n2p73
Álvarez, J., E Medina, X. (2009). Addressing culture in the EFL classroom: A dialogic proposal. Profile: Issues in Teachers' Professional Development, 11(2), 151-170.

Ariza, D. (2007). Culture in theEFL classroomat Universidad de la Salle: An innovation project. Actualidades Pedagógicas, 50, 9-17.

Berg, A., Blank, M., E, Mellaville, A. (2006). Community based learning. Engaging students for success and citizenship. Washington, DC: Coalition for Community Schools.

Cakir, I. (2006). Developing Cultural Awareness in Foreign Language Teaching. Online Submission. Retrieved from: http://dergipark.ulakbim.gov.tr/tojde/article/ view/5000102833/5000095928

Chala, P., \& Chapetón, C. (2013). Undertaking the act of writing as a situated social practice: Going beyond the linguistic and the textual. Colombian Applied Linguistics Journal, 15(1), 25-42. https://doi. org/10.14483/udistrital.jour.calj.2013.1.a02

Chang, B., (2010) The power of geographical boundaries: Cultural, political, and economic border effects in a unitary nation (Unpublished doctoral dissertation). lowa State University, lowa.

Cohen, L., Manion, L., \& Morrison, K. (2007). Research methods in education. London; Routledge.

Dörnyei, Z. (2007). Research methods in applied linguistics. Oxford: Oxford University Press.

Eridafithri, E. (2015) The application of portfolios to assess progress in writing of EFL students at secondary schools in Banda Aceh. Studies in English Language and Education, 2(1), 1-16. https://doi.org/10.24815/ siele.v2i1.2231

Frank, J. (2013). Raising cultural awareness in the English language classroom. English teaching Forum. Retrieved from https://files.eric.ed.gov/fulltext/EJ1020809.pdf

Fulton, M., Kennedi, K., Koslezki, E., E Zion, S. (2005). Cultural identity and teaching: One Point Series. Tempe, AZ: Arizona State University.

Gripaldo, R. (2011). History and cultural identity: The Philippine case. In J. Hogan (Ed.), History and cultural identity. Retrieving the past, shaping the future (pp. 251-273). Washington, DC: The Council for Research in Values and Philosophy.

Jandt, F. E. (2012). An introduction to intercultural communication: Identities in a global community. Los Angeles, CA: Sage Publications.

Lin, L. F. (2009). Second language learners' identity toward their home culture: Adding pragmatic knowledge to language learning curriculum. Asian Social Science, 5(8), 43-51. https://doi.org/10.5539/ ass.v5n8p43 
Lombana, C. (2009). Some issues for the teaching of writing. PROFILE: Issues in Teachers' Professional Development, 3(1), 44-51.

Ministerio de Educación Nacional. (2004). Estándares Básicos de Competencias Ciudadanas. Formar para la Ciudadanía iSí es Posible!. Colombia: IPSA.

Mitchell, L. A. (2009). Becoming Culturally Responsive Teachers in Today's Diverse Classroom. Online Submission. Retrieved from https://files.eric.ed.gov/ fulltext/ED505986.pdf

Norton, B. (2006). Identity as a sociocultural construct in second language education. In K. Cadman $\& \mathrm{~K}$. O'Regan (Eds.), TESOL in Context [Special Issue], 22-33.

Norton, B. (2011). Identity. In J. Simpson (Ed.), The Routledge handbook of applied linguistics (pp. 318330). Taylor \& Francis E-library.

Örnek, Y. (2003). Globalization and cultural identity. Retrieved from: http://studienkreis.org/common/ news/referat_oernek.pdf _

Pennycook, A. (2004). Critical applied linguistics. In A. Davies \& C. Elder (Eds.), The handbook of applied linguistics (pp. 784-807). Oxford: Blackwell Publishing. https://doi.org/10.1002/9780470757000. ch32

Popa, C. (2012). Is globalization a necessary evil? Side effects of the globalization. International Journal of Academic Research in Accounting, Finance and Management Sciences, 2(S1), 243-250.
Rafat, B., Emadzadeh, M., \& Ahmadi, K. (2013). Economic, social and political aspect of globalization on health in developing countries (with segregation). International Journal of Academic Research in Business and Social Sciences, 3(7), 384-402. https://doi.org/10.6007/JJARBSS/v3-i7/61

Sharkey, J. Clavijo, A., \& Ramírez, M. (2016). Developing a deeper understanding of community-based pedagogies with teachers: Learning with and from teachers in Colombia. Journal of Teacher Education 67(3), 1-14. https://doi. org/10.1177/0022487116654005

Sharkey, J., E Clavijo, A. (2012). Promoting the value of local knowledge in ESL/EFL teacher education through community-based field assignments. In B. Medrado \& C. Reichmann (Eds.), Projetos e Praticas na Formacao de Professors de Lingua Inglesa (pp. 39-58). Paraiba, Brasil: Editora Universitaria UFPB.

Suneetha, Y., \& Sundaravalli, G. (2011). Incorporating cross-cultural communication in ELT: A pedagogical approach. National University of Singapore Retrieved from http://www.nus.edu.sg/celc/research/ books/3rdsymposium/123to132-suneetha.pdf

Wang, Y. (2007). Globalization enhances cultural identity. Intercultural Communication Studies, 16(1), 83-86. 